\title{
大規模群杭基礎の動的インピーダンス DYNAMIC IMPEDANCE OF A LARGE SCALE PILE-GROUP
}

\author{
増田 潔*,三浦賢治**, 喜多村英司***, 宮本 裕司**** \\ Kiyoshi MASUDA, Kenji MIURA, Eiji KITAMURA and Yuji MIYAMOTO
}

\begin{abstract}
This paper describes the practical analysis methods for dynamic impedance of pile-group foundation with a large number of piles. Many methods for this problem have been proposed, but these were for pile-group with a small number of piles. It is impossible to expand these methods to the analysis for pile-group with many piles due to the restriction of computer memory capacity and computation expense. Two practical analysis methods are shown in this paper. The applicability of the methods was examined using the results by rigorous method and the forced vibration test results.
\end{abstract}

Keywords : pile-group foundation, dynamic impedance function, practical analysis method, forced vibration test, correlation analysis

群杭基礎, 動的インピーダンス, 実用的解析法, 強制加振実験, シミュレーション解析

\section{1.はじめに}

杭基礎上に建つ構造物の地震時応答をスウェイ・ロッ キングモデルで解析する際には杭基礎の動的インピーダ ンスが必要となる。本論文は, 杭本数が非常に多い大規 模群杭基礎の動的インピーダンスを解析するための実用 的な方法について記述したものである。

杭基礎の地盤との動的相互作用のうち動的インピーダ ンスに関する研究はおおよそ 25 年ほど前より着手さ れ"), 今日までに数多くの研究者により解析と実験・钼 測の両面から遂行された貴重な研究の成果が数多く発表 されている21 10)。しかし，これらの研究のほとんだは単 杭あるいは各柱下に基礎フーチングを設け，これを小口 径の杭数本で支持する基礎形式あるいは全体で多くとも 数十本程度の小規模群杭基礎に関するものである。高層 建物は自重が大きく,この自重に耐え得る強固な基礎が 必要となる。この基礎が杭基礎として計画される場合に は，各柱下に大口径の杭 1 本が支持杭として設計される 場合が多い。さらに，高層建物の平面規模は一般に大き く, 現在では数百本に及ぶ大規模群杭基礎も珍しくない。 この種の杭基礎においては，建物底面の全面に打設され た杭の各々が地震時に相互に影響し合う群杭特有の問題 が生じる。数本程度の小規模群杭基礎に関して得られた 既往の研究成果を外插し, 数百本に及ぶ大規模群杭基礎
の動特性を把握するには限界があると考えられる。

文献 1)１0）における単杭あるいは群杭基礎の解析 は弾性波動論に基づくものである。これらの文献で用い られている解析方法を大規模群杭基礎に適用すること は, 計算機の記憶容量や演算時間の制約により実際上不 可能である。これに対し, 群杭基礎の動的インピーダン スを解析する簡便で実用的な解析方法として, Dobry ${ }^{11}$, Gazetas $^{121}$, Makris ${ }^{13)}$ が提案した方法がある。これは杭 からの波動冕散の伝播経路を設定する解析法であり，波 動逸散の伝播経路が均質地盤においては比較的簡単に定 まることから有効な方法である。しかし，実在の地盤に おいては均質地盤として取り扱うことのできる地盤はま れである。特に，杭支持構造物が計画・建設される軟弱 地盤では、物性値の異なる軟弱な地層が上部に数層あり, その深部に強固な支持層が存在するのが普通である。こ の種の成層地盤において上記の解析法を適用するために は，便宜的に成層地盤を等価な均質地盤に置換する方法 など解決しなければならない問題が多々ある。

本論文は大規模群杭基礎の動的インピーダンスの簡便 で実用的な解析法を示し，この解析法の適用性を精度の 高い解析法による結果および群杭基礎で実施した強制加 振実験の結果を用いて検討したものである。
本論文は文献 15）で既に発表した内容に加筆したものである。

* 鹿島, 情報システム部 次長

** 鹿島, 小堀研究室 次長・博士 (工学)

*** 鹿島, 情報システム部 主任

**** 鹿島, 小煀研究室 主任研究員・博士 (工学)
Information Processing Center, Kajima Corporation Kobori Research Complex, Kajima Corporation, Dr. Eng. Information Processing Center, Kajima Corporation Kobori Research Complex, Kajima Corporation, Dr. Eng. 


\section{2. 動的インピーダンスの解析法}

本章では, 群杭基礎の動的インピーダンス（以後, $D I$ と略記する。）の解析法として，解析精度の高い方 法とこれを簡便にした方法および杭頭外力の分布を仮定 して解析する方法について示す。

\section{1 精算法}

$N$ 本の杭から成る群杭基礎の各杭を $m$ 個の要素に分 割し，各要素間節点に Fig. 1 の変位成分を有する変位 ベクトル $\left\{u^{j i}\right\}$ :

$$
\left\{u^{J i} \mid=\left\{u_{x}^{J i}, u_{y}^{J i}, u_{z}^{j i}, \phi_{x}^{J i},\left.\phi_{y}^{J i}\right|^{T}\right.\right.
$$

とこの変位べクトルに対応する節点外力ベクトル $\left\{f^{J}\right\}$ :

$$
\left\{f^{J i}\right\}=\left\{p_{x}^{J i}, p_{y}^{J i}, p_{z}^{J i}, M_{x}^{J i}, M_{y}^{J i}\right\}^{T}
$$

を考える。ただし， $J=1 \sim N, i=1 \sim(m+1)$ であり， 上添字 $J$ は杭番号, また $i$ は節点番号であり， $i$ は杭頭 位置を 1 とする。なお，杭軸回りのねじれ角 $\phi_{z}^{J}$ とモ一 メント $M_{z}^{J i}$ が群杭の $D I$ に及ぼす影響は小さいため, こ れらは無視する。以下はすべて振動数領域での解析であ

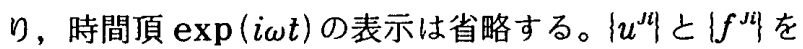
全杭についてまとめだベクトルをそれぞれ $\left\{u_{P}\right\}$ と $\left\{f_{P}\right\}$ と すると，これらのベクトル間には次の関係がある。

$$
\begin{aligned}
& {\left[S_{P}\right]\left\{u_{P}\right\}=\left\{f_{P}\right\}} \\
& {\left[S_{P}\right]=\left[G_{s s}\right]^{-1}+\left[S_{P P}\right]-\left[S_{S P}\right]}
\end{aligned}
$$

ここに, $\left[G_{s s}\right]$ は自由地盤のグリーン関数， $\left[S_{p p}\right]$ は杭体 の剛性, $\left[S_{S P}\right]$ は杭位置地盤すなわち土柱の剛性マトリッ クスである。 $\left\{u_{P} \mid,\left\{f_{P}\right\}\right.$ を杭頭に関する成分 $\left\{u_{P 1}\right\},\left\{f_{P 1}\right\}$ とそ れ以外の成分 $\left\{u_{P 2} \mid,\left\{f_{P 2}\right\}\right.$ とに分けると，(2-1) 式を次式 のごとく畫き換えることができる。

$$
\left[\begin{array}{ll}
{\left[S_{P 11}\right]} & {\left[S_{P 12}\right]} \\
{\left[S_{P 21}\right]} & {\left[S_{P 22}\right]}
\end{array}\right]\left\{\begin{array}{l}
\left\{u_{P 1}\right\} \\
\left.\mid u_{P 2}\right\}
\end{array}\right\}=\left\{\begin{array}{l}
\left\{f_{P 1}\right\} \\
\left\{f_{P 2}\right\}
\end{array}\right\}
$$

$D I$ の解析時には杭頭外力 $\left\{f_{P 1}\right\}$ 以外は存在せず, $\left\{f_{P 2}\right\}=0$ として (3) 式を解くと $\left\{f_{P 1}\right\}$ は次式となる。

$$
\begin{aligned}
& \left\{f_{P 1}\right\}=\left[S_{H}\right] \cdot\left\{u_{P 1}\right\} \ldots \ldots \ldots \ldots \ldots \ldots \ldots \ldots \ldots \ldots \ldots \ldots \ldots \\
& {\left[S_{H}\right]=\left[S_{P 11}\right]-\left[S_{P 12}\right] \cdot\left[S_{P 22}\right]^{-1} \cdot\left[S_{P 21}\right]}
\end{aligned}
$$

杭頭上の基礎フーチングを剛体とし，Fig. 2 に示す成分 を基礎フーチングの変位ベクトル $\left\{U_{F}\right\}$ とする。

$$
\left.\mid U_{F}\right\}=\left\{U_{x}, U_{y}, U_{z}, \Phi_{x}, \Phi_{y}, \Phi_{z}\right\}^{T}
$$

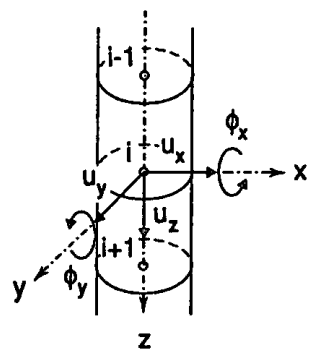

Fig. 1 Elements of Displacement Vector at Pile Nodes
また、この変位ベクトルに対応する基礎フーチングの外 カベクトルを $\left\{f_{F}\right\}$ とする。

$$
\left|f_{F}\right|=\left\{F_{x}, F_{y}, F_{z}, M_{x}, M_{y}, M_{z}\right\}^{T}
$$

この $\left\{U_{F}\right\}$ と $\left\{u_{P 1}\right\}$ は基礎フーチングの拘束マトリックス $[R]$ を介して,

$$
\left\{u_{P_{1}}\right\}=[R] \cdot\left\{U_{F}\right\} \text {. }
$$

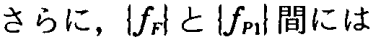

$$
\left\{f_{F}\right\}=[R]^{T} \cdot\left\{f_{P 1}\right\}
$$

の関係にある。

(4-1) 式と（6-1）式を（6-2）式に代入すると, 次式 が求まる。

$$
\begin{aligned}
& \left\{f_{F}\right\}=\left[K_{P}\right] \cdot\left\{U_{F}\right\} \cdots \cdots \cdots \\
& {\left[K_{P}\right]=[R]^{T} \cdot\left[S_{H}\right] \cdot[R]}
\end{aligned}
$$

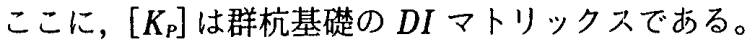

上記の解析法は, 杭の離散化による誤差妾除けば厳密 解法であり, 以後, この解析法を精算法（図中では, RIGOROUS と記す。) と呼ぶ。

精算法でのマトリックスは, $\left[G_{s s}\right]$ が $5 N(m+1)$ 次, $\left[S_{P_{22}}\right]$ が $5 \mathrm{Nm}$ 次正方マトリックスまた $[R]$ が $(5 \mathrm{~N}, 6)$ 型マトリックスであり，大次数のマトリックスの演算が 必要となる。例えば $N=100, m=10$ の場合, $\left[G_{s s}\right]$ は 5500 次, $\left[S_{P 22}\right]$ が 5000 次正方, $[R]$ が $(500,6)$ 型マト リックスとなり，これらのマトリックス演算を行うこと は実用上困難である。

\section{2 略算法}

群杭基礎中の I 杭と J 杭の 2 本杭に関して（2）式一 (4) 式の計算を行うと, 2 本杭間の杭頭変位 $\left\{u_{P 1}\right\}$ と杭 頭外力ベクトル $\left\{f_{P 1}\right\}$ との関係式が (4-1) 式より求まる。 この関係を次式で表現する。

$$
\left\{\begin{array}{l}
\left\{u_{P 1}^{\prime}\right\} \\
\left\{u_{P 1}^{J}\right\}
\end{array}\right\}=\left[\begin{array}{ll}
{\left[D^{I J}\right.} & {\left[D^{I J}\right]} \\
{\left[D^{J I}\right]} & {\left[D^{J J}\right]}
\end{array}\right]\left\{\begin{array}{l}
\left\{f_{P 1}^{I}\right\} \\
\left\{f_{P 1}^{J}\right\}
\end{array}\right\}
$$

ここに，IとJはそれぞれ I 杭と J 杭に関係する量

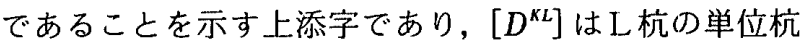
頭外力に対する $\mathrm{K}$ 杭の杭頭変位マトリックスすなわち杭 頭柔性マトリックスである。

（8）式を群杭基礎中の全ての 2 本杭の組合せについ

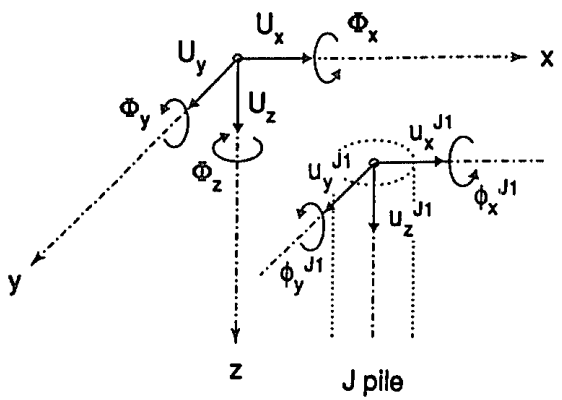

Fig. 2 Elements of Displacement Vector for Foundation Slab and Pile Head 
て計算すると, 群杭基礎全体での杭頭変位 $\left\{u_{P_{1}}\right\}$ と杭頭 外力ベクトル $\left\{f_{P 1}\right\}$ の関係を次式のごとく表現すること ができる。

$$
\begin{aligned}
& \left\{u_{P 1}\right\}=[D] \cdot\left\{f_{P_{1}}\right\} \cdots \\
& \left\{f_{P_{1}}\right\}=[D]^{-1} \cdot\left\{u_{P 1}\right\}
\end{aligned}
$$

ここに, [D]は 2 本杭間で求めた杭頭柔性マトリックス $\left[D^{\kappa L}\right]$ を群杭基礎全体についてまとめた杭頭柔性マト リックスである。(9-2) 式と精算法の (4-1) 式は同一 の関係式であり, $[D]^{-1}$ を $\left[S_{H}\right]$ と置くことにより，(7-2) 式から群杭基礎の $D I$ マトリックス $\left[K_{P}\right]$ を計算するこ とができる。

上記の方法は 2 本杭間の杭頭柔性マトリックスの重ね 合わせにより $D I$ を解析する方法である。この方法は杭 頭柔性マトリックスの計算時に 2 本杭以外の杭の影響が 考慮されていないことから近似解法である。この近似解 法では $\left[G_{s s}\right]$ が $10(m+1)$ 次, $\left[S_{P 22}\right]$ が $10 m$. 次正方、ト リックスとなり，精算法におけるマトリックスの次数が 大幅に縮小される。さらに，解析する方向を限って，例 えば $x$ 軸と $z$ 軸方向に関係する $D I$ を解析する場合に は (8) 式の杭頭変位, 杭頭外力ベクトルを,

$$
\begin{aligned}
& \left\{u_{P_{1}}^{j}\right\}=\left\{u_{x}^{J 1}, \phi_{y}^{J 1}, u_{z}^{J 1}\right\}^{T} \ldots \ldots \ldots \ldots \ldots \ldots \ldots \\
& \left\{f_{P_{1}}^{J}\right\}=\left\{p_{x}^{j 1}, M_{y}^{\prime 1}, p_{z}^{J 1}: p_{y}^{J 1}=M_{x}^{J 1}=0\right\}^{T} .
\end{aligned}
$$

また, (5) 式の基礎フーチングの変位ベクトル, 外力 ベクトルを

$$
\begin{aligned}
& \left\{U_{F}\right\}=\left\{U_{x}, \Phi_{y}, U_{z}\right\}^{T} \\
& \left\{f_{F}\right\}=\left\{F_{x}, M_{y}, F_{z}\right\}^{T}
\end{aligned}
$$

とすることにより， $[D]$ を $N$ 次の正方また $[R]$ を $(3 N, 3)$ 型マトリックスとすることができる。この時 の $D I$ マトリックスは次式となる。

$$
\left\{\begin{array}{c}
F_{x} \\
M_{y} \\
F_{z}
\end{array}\right\}=\left[\begin{array}{ccc}
K_{H H} & K_{H R} & 0 \\
K_{R H} & K_{R R} & 0 \\
0 & 0 & K_{V V}
\end{array}\right]\left\{\begin{array}{l}
U_{x} \\
\Phi_{y} \\
U_{z}
\end{array}\right\}
$$

ここに，K $K_{H H}, K_{R R}, K_{V V}$ はそれぞれ水平, 回転, 上下の, また $K_{H R}=K_{R H}$ は水平と回転の連成項の $D I$ である。

一方, この解法においては群杭基礎内の杭間距離 $s$ と方位角 $\theta$ が異なるすべての 2 本杭の組合せについて 杭頭柔性マトリックス $\left[D^{\kappa L}\right]$ を計算する必要がある。杭 本数が多くなると，この組合せ数も膨大になり，[ $\left[D^{K L}\right]$ の計算に時間がかかることになる。Fig. 3 において I 杭 の杭頭を $x$ 軸方向の単位外力 $p_{x}^{\prime 1}=1$ で加振した時の杭 間距離 $s$, 方位角 $\theta$ にある $\mathrm{J}$ 杭の (10-1) 式に対応す る杭頭変位ベクトルを $\{\delta(s, \theta)\}$ ：

$$
\{\delta(s, \theta)\}=\left\{u_{x}(s, \theta), \phi_{y}(s, \theta), u_{z}(s, \theta)\right\}^{T}
$$

とすると,この変位べクトルは杭間距離 $s$ が同一で $x$ 軸よ $y$ 軸上にある杭の杭頭変位を用いで次式で与えら れる。

$$
\{\delta(s, \theta)\}=[T] \cdot\left[T_{\theta}\right] \cdot\{\delta(s)\}
$$

$$
\begin{aligned}
\{\delta(s)\}= & \mid u_{x}(s, 0), u_{x}(s, 90), u_{z}(s, 0), \\
& \left.\phi_{y}(s, 90), \phi_{y}(s, 0)\right\}^{r} \ldots \ldots \ldots \ldots .
\end{aligned}
$$

また， $[T]$ は次式の座標変換マトリックスである。

$$
[T]=\left[\begin{array}{ccccc}
C o & -S i & 0 & 0 & 0 \\
0 & 0 & 0 & S i & C o \\
0 & 0 & 1 & 0 & 0
\end{array}\right]
$$

$$
(C o=\cos \theta, \quad S i=\sin \theta)
$$

さらに, $\left[T_{\theta}\right]$ は次式のフーリ工級数展開に関するマト リックスである。

$$
\begin{aligned}
{\left[T_{\theta}\right]=} & {\left[\begin{array}{ccccc}
C^{*} & 0 & 0 & 0 & 0 \\
0 & S^{*} & 0 & 0 & 0 \\
0 & 0 & C^{*} & 0 & 0 \\
0 & 0 & 0 & -S^{*} & 0 \\
0 & 0 & 0 & 0 & C^{*}
\end{array}\right] \ldots \ldots \ldots . } \\
\left(C^{*}=\cos \eta \theta,\right. & \left.S^{*}=-\sin \eta \theta\right)
\end{aligned}
$$

ただし， $\eta=1$ である。また，I 杭の $y$ 軸回りモーメン 卜加振 $M_{y}^{n}, z$ 軸方向加振 $p_{z}^{\prime \prime}$ に関しても同様に (17) 式においてそれぞれ $\eta=1, \eta=0$ とすることにより（14） 式の関係式が成り立つ。

ここで, $\{\delta(s)\}$ の各要素は杭間距離 $s$ のみの関数であ り，任意の 1 要素を $\delta^{*}(s)$ とおき,これを次式で近似す る。

$$
\left.\delta^{*}(s)=\{a /(s+b)\} \cdot \exp [-i \mid(\omega s / v)+c\}\right] \cdots(18)
$$

ここに， $\omega$ は加振円振動数， $v$ は位相速度，また $a ， b$, $c$ は定数である。次に, 杭頭加振杭から距離 $s_{1}$ と $s_{2}$ に ある杭の杭頭変位を,

$$
\begin{aligned}
& \delta^{*}\left(s_{1}\right)=A_{1} \cdot \exp \left(i \theta_{1}\right) \\
& \delta^{*}\left(s_{2}\right)=A_{2} \cdot \exp \left(i \theta_{2}\right)
\end{aligned}
$$

で表す。ここに，Aおよび $\theta$ ，は距離 $s_{j}$ にある杭の杭 頭変位の振幅および加振力との位相角である。(19) 式 より，(18）式中の定数 $a, b, c$ は次式のごとく求まる。

$$
\begin{aligned}
& a=-A_{1} \cdot A_{2} \cdot\left(s_{2}-s_{1}\right) /\left(A_{2}-A_{1}\right) \\
& b=\left(A_{1} \cdot s_{1}-A_{2} \cdot s_{2}\right) /\left(A_{2}-A_{1}\right) \cdots \\
& c=\left(\theta_{2} \cdot s_{1}-\theta_{1} \cdot s_{2}\right) /\left(s_{2}-s_{1}\right) \cdots \ldots . \\
& v=-\omega \cdot\left(s_{2}-s_{1}\right) /\left(\theta_{2}-\theta_{1}\right) \cdots \ldots \ldots \ldots
\end{aligned}
$$

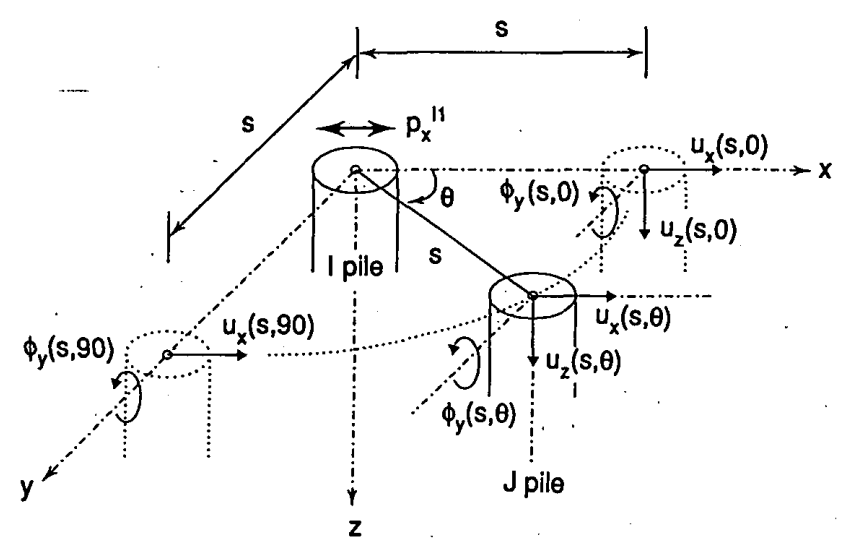

Fig. 3 Fourier Series Expansion of Displacement Vectors at Pile Heads 
ここで, 位相速度 $v$ は受振杭の剛性と質量が影響す るために加振杭からの地盤への逸散波の位相速度とは異 なる。(19) 式の杭頭変位を算定する杭は, 加振杭から の距離が $s_{i}=s_{\min }+(i-1)(1 / 4) \lambda\left(i=1,2 \cdots, s_{\min }\right.$ : 最 小杭間隔， $\lambda$ : 地盤系における最小横波速度層の横波の 波長) にある杭とし， $s_{i}$ 之 $s_{i+1}$ 位置の杭の変位を用い て (20) 式から定数を決め, $s_{i}$ と $s_{i+1}$ の間にある杭の 杭頭变位は (18) 式より算定する。以後, 上記の解析法 を略算法（図中では，APPROX．と記す。）と呼ぶ。

\section{3 応力加振法}

基礎フーチングの加振力に対応する杭頭外力の分布を 付録に示す一様と剛版分布に仮定して，この杭頭外力に よる杭頭変位の平均值を基礎フーチングの変位とするこ とにより，群杭基礎の $D I$ を近似的に算定することがで きる。例えば，基礎フーチングの水平加振 $\left(F_{x}\right)$ の場合 には水平杭頭外力 $p_{x}^{J 1}: J=1 \sim N$ の分布を仮定し, (10) 式において $p_{z}^{J_{1}}=M_{y}^{J_{1}}=0$ また $\phi_{y}^{\prime 1}=0$ と置くと $(9-1)$ 式 より杭頭水平変位 $u_{x}^{\prime \prime}$ が求まる。同樣に，回転と上下加 振の場合は上下杭頭外力 $p_{z}^{\prime \prime}$ の分布を仮定して杭頭上下

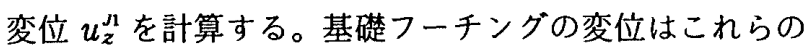
杭頭変位のエネルギー平均として, 水平変位 $U_{x}$, 回転 角 $\Phi_{y}$ および上下変位 $U_{z}$ を求め, 杭頭外力の総和から 基礎フーチングに作用する水平 $F_{x}$ ，回転モーメント $M_{y}$ および上下外力 $F_{z}$ を算定することにより，DI を次式 で求める。

$$
\begin{aligned}
& K_{H H}=F_{x} / U_{x} \\
& K_{R R}=M_{y} / \Phi_{y} \\
& K_{v V}=F_{z} / U_{z}
\end{aligned}
$$

ここに,

$$
\begin{aligned}
& U_{x}=\sum_{J=1}^{N} p_{x}^{\jmath} \cdot u_{x}^{J 1} / \sum_{J=1}^{N} p_{x}^{J 1} \\
& \Phi_{y}=\sum_{J=1}^{N} p_{z}^{\jmath 1} \cdot u_{z}^{\jmath l} / \sum_{J=1}^{N} p_{z}^{\jmath 1} \cdot x_{J} \\
& U_{z}=\sum_{J=1}^{N} p_{z}^{J 1} \cdot u_{x}^{J 1} / \sum_{j=1}^{N} p_{z}^{J} \\
& F_{x}=\sum_{J=1}^{N} p_{x}^{j 1} \\
& M_{y}=\sum_{J=1}^{N} p_{z}^{J_{1}} \cdot x_{J} \\
& F_{z}=\sum_{J=1}^{N} p_{z}^{J_{1}}
\end{aligned}
$$

ただし， $x_{J}$ は群杭の中立軸から杭までの距離である。 以後, 上記の解析法を応力加振法と呼ぶ。なお, 応力加 振法では, (12) 式の $D I$ マトリックスのうち連成項 $K_{H R}=K_{R H}$ を算定することはできない。

\section{3. 動的インピーダンス}

前章で示した 3 種類の解析法で $D I$ を解析し, これら の解析法の特徵之適用性について調べる。

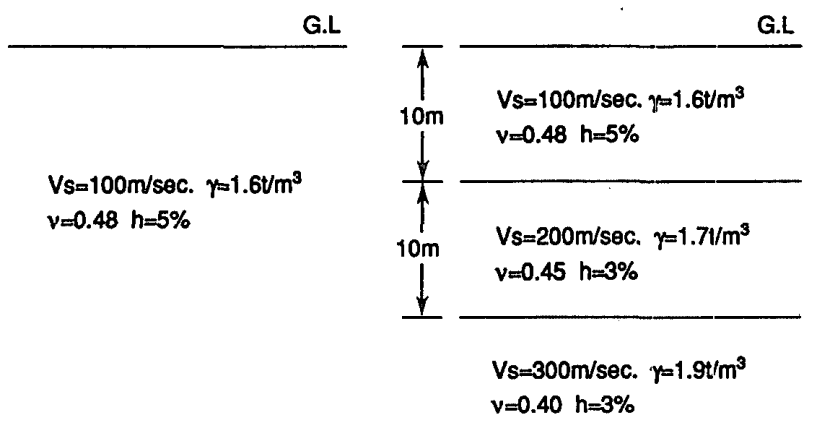

(a) S-1 SOIL

(b) S-2 SOIL

Fig. 4 Soil Conditions

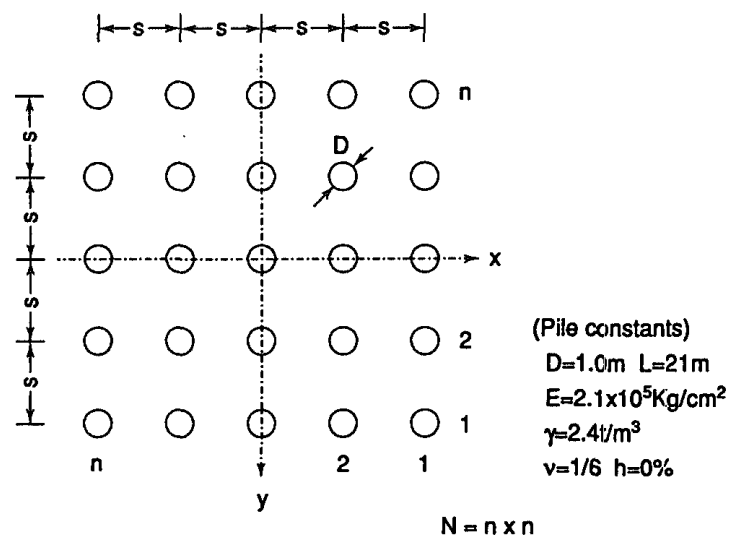

Fig. 5 Pile Arrangement

\section{1 解析条件}

$D I$ の解析は, Fig. 4 に横波速度 $V_{s}$, 単位体積重量 $\gamma$, ポアソン比 $\nu$, 減衰定数 $h$ を示す均質地盤 (S-1. SOIL) 亡支持層を有する 3 層の成層地盤 (S-2 SOIL) の 2 種 類の地盤に, Fig. 5 に諸元を示す軸径 $1 \mathrm{~m}$ で杭長 $21 \mathrm{~m}$ の杭が正方格子状に配列された群杭基礎を対象にして行 う。

\section{2 略算法の検討}

Fig. 6 は加振杭から $s_{1}$ と $s_{2}$ の距離にある杭間の杭頭 変位の位相速度 $v$ を $s_{2}-s_{1}=2.5 \mathrm{~m}$ として (20-4) 式 から計算した結果である。 $x$ 軸方向加振力 $\left(p_{x}\right)$ 時の同 軸上にある杭の杭頭変位 $\left(u_{x}(s, 0)\right)$ の位相速度は, 地 表面層の横波速度 $V_{s}(=100 \mathrm{~m} / \mathrm{sec}$.$) とこの層の縦波$ 速度 $V_{P}(=510 \mathrm{~m} / \mathrm{sec}$. ) の間にあり，位相速度が速く なる位置がある。均質地盤においては $s=40 \mathrm{~m}$ と $85 \mathrm{~m}$ 付近で位相速度が速くなる位置があるが，これは縦波の 波長 $L_{P}\left(=V_{P} / f=510 / 3=170 \mathrm{~m}\right)$ の $1 / 4$ 波長 $(42.5 \mathrm{~m})$ の奇数倍距離に関係し，加振杭から発した縱波が加振杭 の振動と逆位相となる位置に相当する。成層地盤におい ては下部層の影響を受け，位相速度の速くなる位置が遠 くなる。 $p_{x}$ 加振時における加振方向直交 $y$ 軸上の杭の 杭頭変位 $\left(u_{x}(s, 90)\right)$ の位相速度はほぼ最小横波速度で あり，成層地盤の方が位相速度が均質地盤に比べ若干速 くなっている。上下加振力 $\left(p_{z}\right)$ 時の杭頭上下変位 

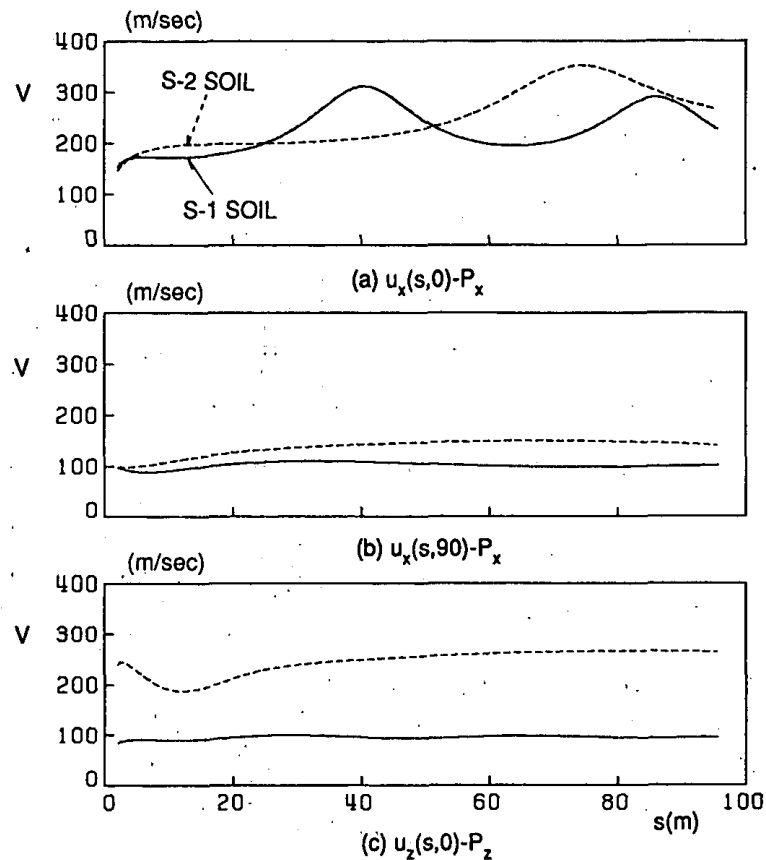

Fig. 6 Phase Velocity of Two Pile System : $f=3.0 \mathrm{~Hz}$

$\left(u_{z}(s, 0)=u_{z}(s, 90)\right)$ の位相速度は，均質地盤では横 波速度より若干遅く，成層地盤では第 2 層 $\left(V_{s}=200\right.$ $\mathrm{m} / \mathrm{sec}$. ) と支持層 $\left(V_{s}=300 \mathrm{~m} / \mathrm{sec}.\right)$ の横波速度の間 の値になっている。

Fig. 7 と Fig. 8 は，杭頭変位を（18）式の近似式で 計算した結果 (APPROX.) と精算法 (RIGOROUS) のそれとの比較を示す。加振方向および地盤種別によら ず，両者は良く一致しており，略算法での杭頭変位の近
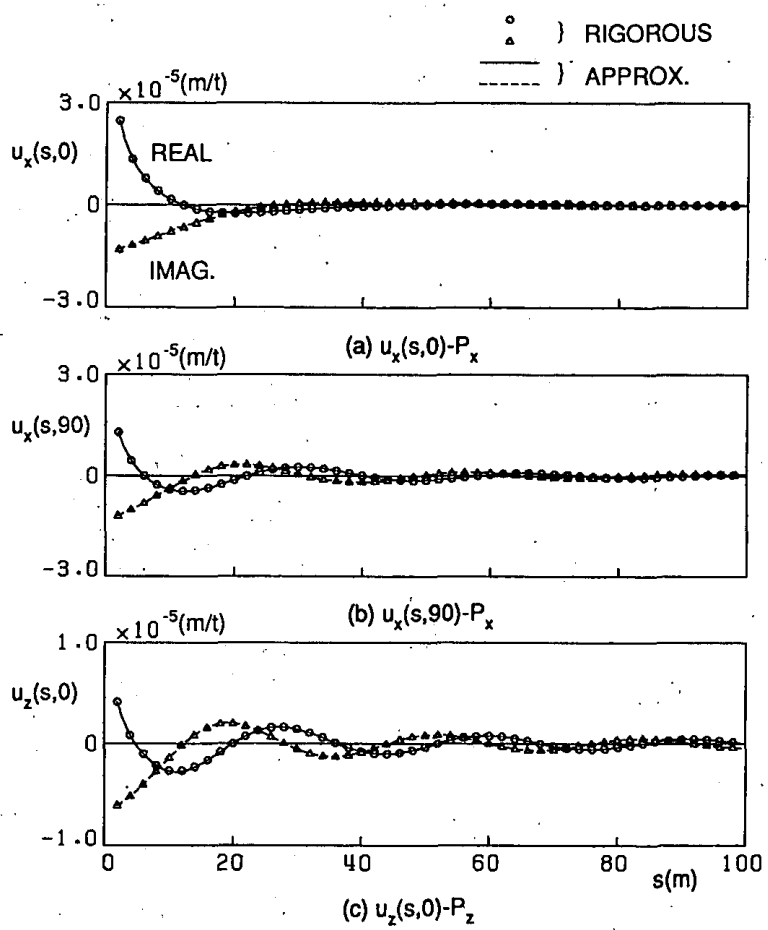

Fig. 7 Approximation of Displacement Vectors at Pile Heads : S-1 SOIL, $f=3.0 \mathrm{~Hz}$
似が妥当であることが分かる。

Fig. 9 とFig. 10 は, $4(2 \times 2), 16(4 \times 4), 36(6 \times 6)$ 本群杭基礎の水平 $K_{H H}$ と回転 $K_{R R}$ の $D I$ に関する精算法 と略算法との比較を示す。略算法の $D I$ は実部, 虚部と も精算法に比べ小さくなる傾向にある。これは略算法で は 2 本杭間の杭頭柔性を重わ合わせて $D I$ を計算してお り，この際に他の杭の影響が考慮されていないことによ る。さらに杭本数が多い. $64(8 \times 8)$ 本群杭基礎の DI に 関する精算法と略算法との比較を Fig. 11 と Fig. 12 に 示す。連成項 $K_{H R}$ 以外の $D I$ に関しては略算法と精算法 との上記の差異の傾向は杭本数が増加してもほぼ同じで ある。略算法の連成項 $K_{H R}$ の実部は精算法に比へ過少評 価になっている。同図の解析に要した略算法の演算時間 は，精算法のそれの約 $1 / 20$ である。これ以上の本数の 群杭基礎の $D I$ を精算法により解析することは計算機の 制約により不可能であり，杭本数がさらに増えた場合の 略算法と精算法との差異の傾向は, 連成項 $K_{H R}$ を除き変 わらないものと考えられる。

Fig. 11 とFig. 12 に示した $D I$ の精算法と略算法との 差異が，この群杭基礎上にある建物の地震時応答特性に 及ぼす影響についで調べる。'建物は階高 $3 \mathrm{~m}$ の 10 階建 て鉄筋コンクリート造を想定し，基礎は平面が $20 \mathrm{~m} \times$ $20 \mathrm{~m}$ で $64(8 \times 8)$ 本の群杭とする。建物モデルは基礎 フーチングを含め 11 質点とし, 基礎フーチング下端に 群杭基礎の $D I\left(K_{H H}, K_{H R}, K_{R R}\right)$ を付けたスウェイ・ロッ キングモデルを解析に用いる。上部階の質点重量 $480 \mathrm{t}$, 基礎フーチング重量 $800 \mathrm{t}$ また回転慣性は基礎フーチン
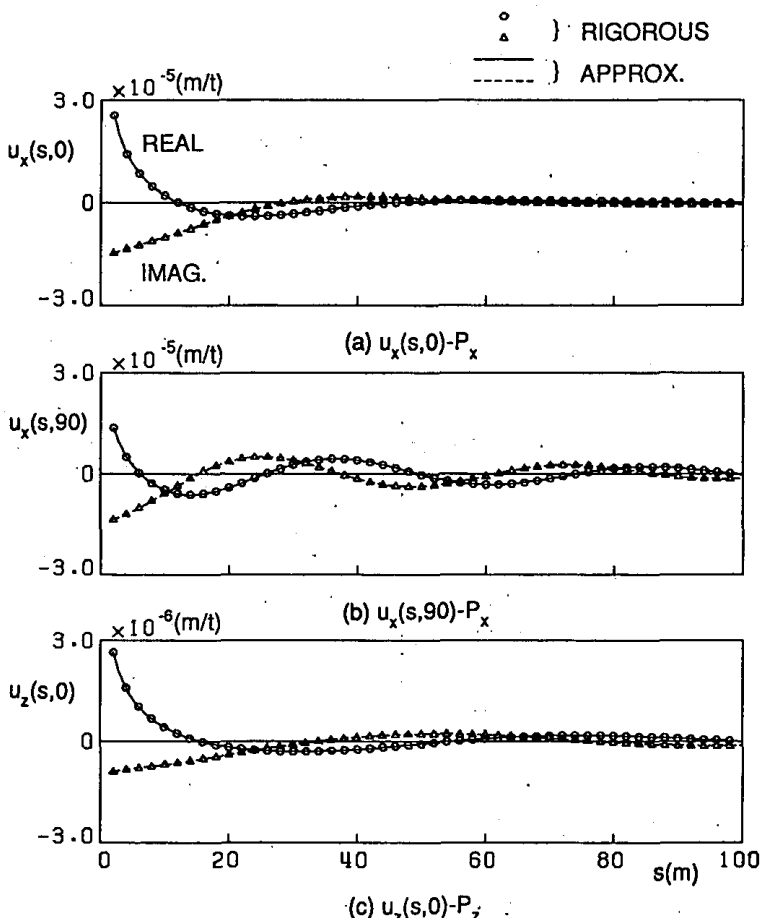

Fig. 8 Approximation of Displacement Vectors at Pile Heads : S-2 SOIL,$f=3.0 \mathrm{~Hz}$ 

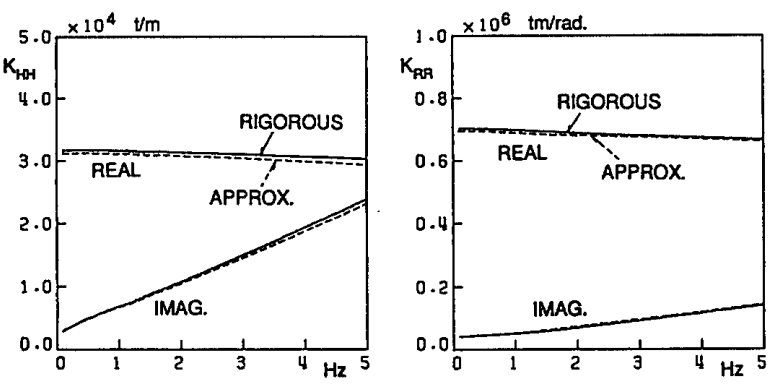

(a) $\mathrm{N}=4(2 \times 2)$
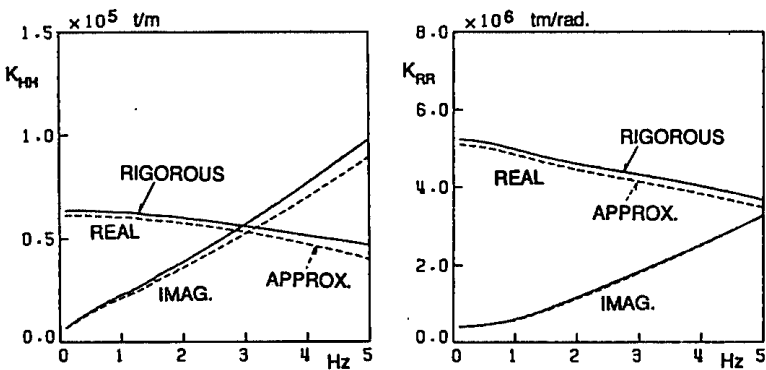

(b) $\mathrm{N}=16(4 \times 4)$
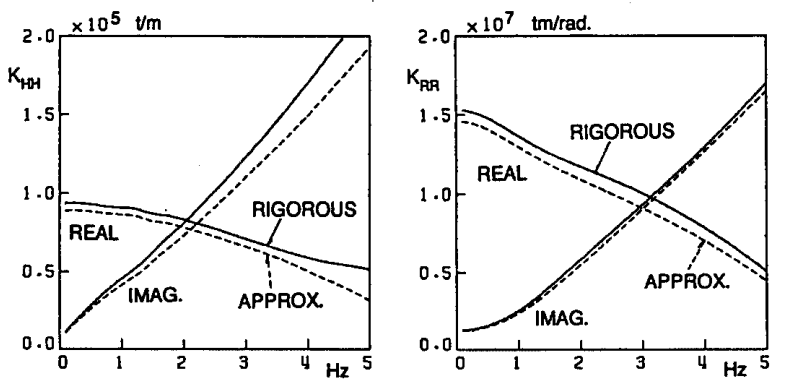

(c) $\mathrm{N}=36(6 \times 6)$

Fig. 9 Dynamic Impedance of $4(2 \times 2), 16(4 \times 4)$ and $36(6 \times 6)$ Pile Group : $S-1$ SOIL, $s / D=2.5$
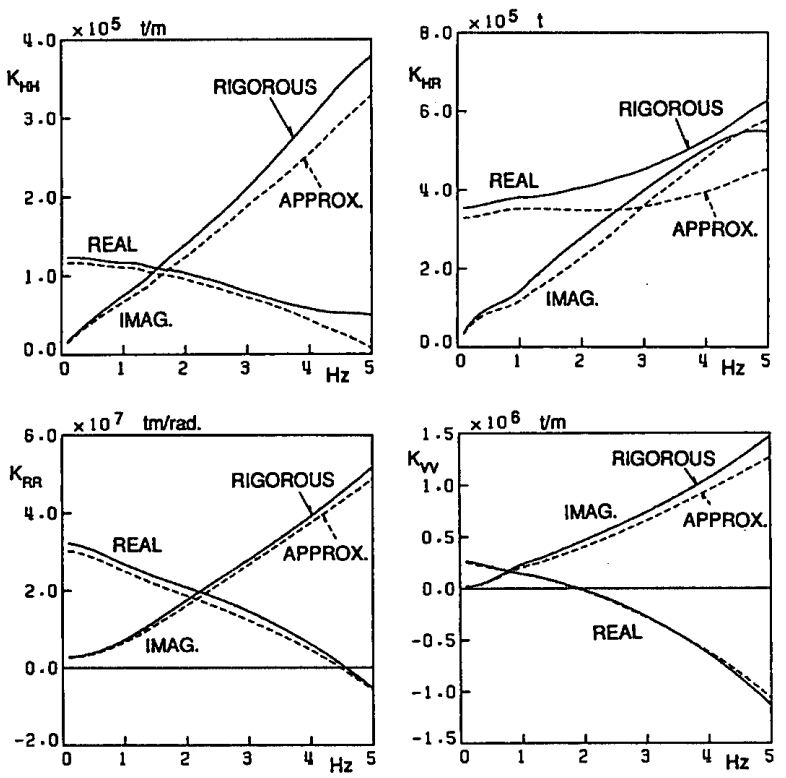

Fig. 11 Dynamic Impedance of $64(8 \times 8)$, Pile Group : S-1 SOIL, $s / D=2.5$

グ下端に集約して $6.07 \times 10^{5} \mathrm{tm}^{2}$ とする。各階を結ぶせ ん断ばねの剛性は，線形に変化するものとして基礎固定 時の 1 次周期 $T_{1}$ が $T_{1}=0.02 H(H:$ 軒高 $)=0.02 \times 30$
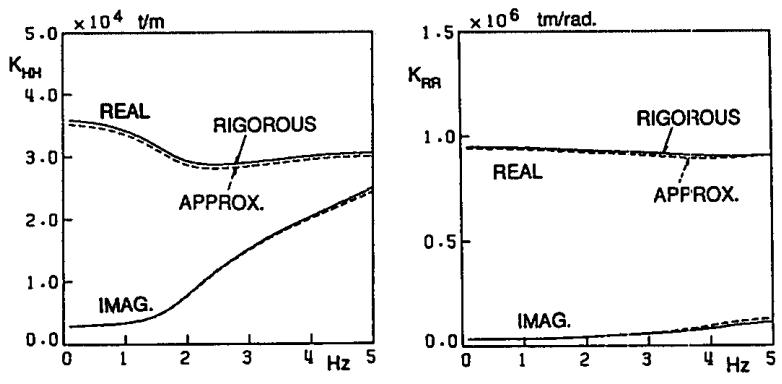

(a) $\mathrm{N}=4(2 \times 2)$
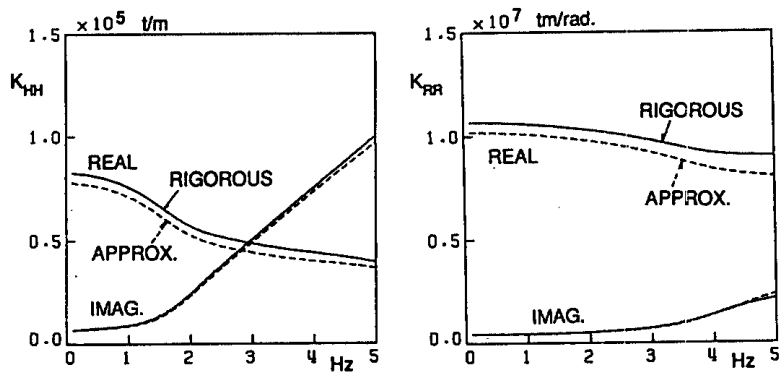

(b) $\mathrm{N}=16(4 \times 4)$
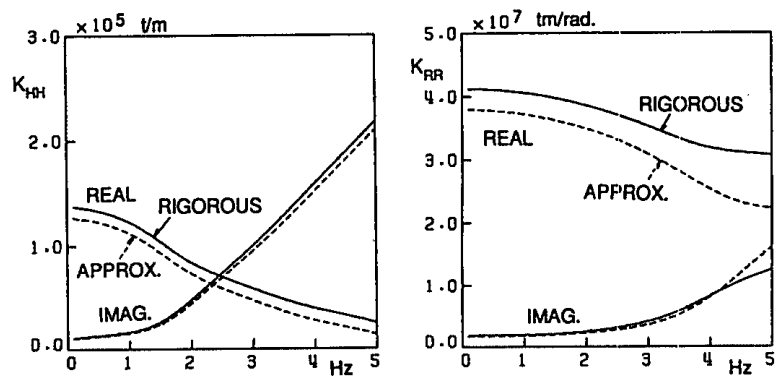

(c) $\mathrm{N}=36(6 \times 6)$

Fig. 10 Dynamic Impedance of $4(2 \times 2), 16(4 \times 4)$ and $36(6 \times$ 6) Pile Group : $\mathrm{S}-2$ SOIL, $s / D=2.5$
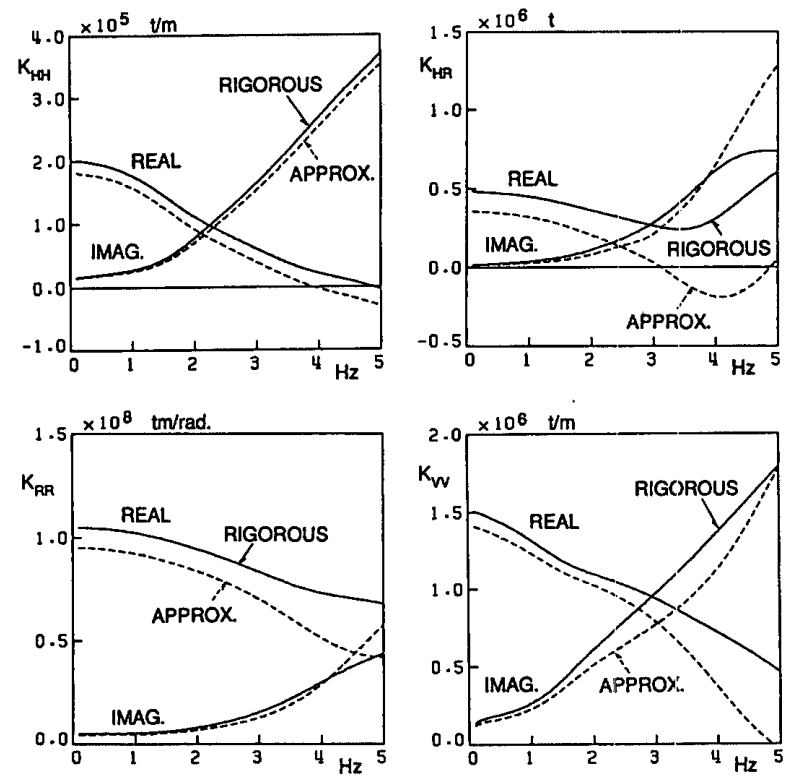

Fig. 12 Dynamic Impedance of $64(8 \times 8)$, Pile Group : S-2 SOIL, $s / D=2.5$

$\mathrm{m}=0.6$ 秒となるように定め，最上階で $1.89 \times 10^{5} \mathrm{t} / \mathrm{m}$, 最下層でその 1.4 倍とする。減衰はせん断ばねが $3 \%$ の堿衰定数を有する複素ばねとして評価する。Fig. 13 

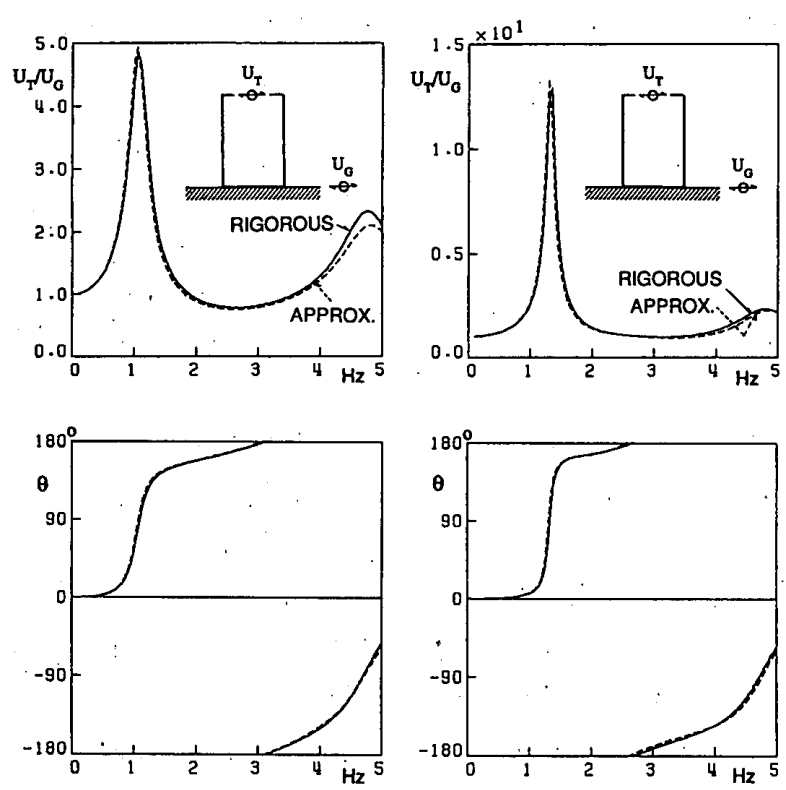

(a) S-1 SOIL

(b) S-2 SOIL

Fig. 13 Frequency Response Curves for 10-Stories Building on $64(8 \times 8)$ Pile Group

は水平方向地震入力時の建物頂部と地表面間の伝達関数 を示す。精算法と略算法の $D I$ を用いた建物頂部の伝達 関数には有意な差異は認められず，建物の地震時応答特 性は略算法の $D I$ を用いることにより工学的に十分な精 度で把握できる。

\section{3 応力加振法の検討}

杭頭外力の分布を剛版 (R) と一様 (U). 分布として 応力加振法で計算した 400 本 $(20 \times 20)$ 群杭基礎の DI を略算法と比較して Fig. 14 に示す。地盤種別によらず， 低振動数領域での応力加振法による $D I$ は, 略算法に比 べ剛版，一様分布の順に若干小さく評価されている。応 力加振法においては，杭頭変位が基礎フーチングにより 拘束される効果が考慮されていないことにより，DI が 高振動数領域において波打つ特性が現れる。しかし，低 振動数領域での群杭基礎の $D I$ が必要となる固有振動数 が非常に低い高層建物の地震応答解析には, 応力加振法 は十分に適用できる。

\section{4 群杭係数}

群杭と単杭の $D I$ の実部の静的值すなわち静的剛性に ついて次式の比を取り，これらの比を群杭係数 $\beta$ と定 義する。この群杭係数と杭本数 $N$ との関係について調 ベる。

$$
\begin{aligned}
& \text { 水平 : } \beta_{H H}=\chi_{H H} /\left(N \cdot \boldsymbol{x}_{H H}^{(S)}\right) \text {. } \\
& \text { 回転: } \beta_{R R}=\chi_{R R} /\left(N \cdot x_{R R}^{(S)}+\chi_{V V}^{(S)} \cdot \sum_{i=1}^{N} x_{i}^{2}\right) \\
& \text { 上下 : } \beta_{v v}=\chi_{v v} /\left(N \cdot x_{v v}^{(S)}\right)
\end{aligned}
$$

ここに， $x_{H H}, x_{R R}, x_{V V}$ はそれぞれ水平，回転，上下の $D I$ の実部の静的值（計算では $0.1 \mathrm{~Hz}$ での値を用いる。）で あり，上添字 $(s)$ は単杭に関する量である。Fig. 15 は
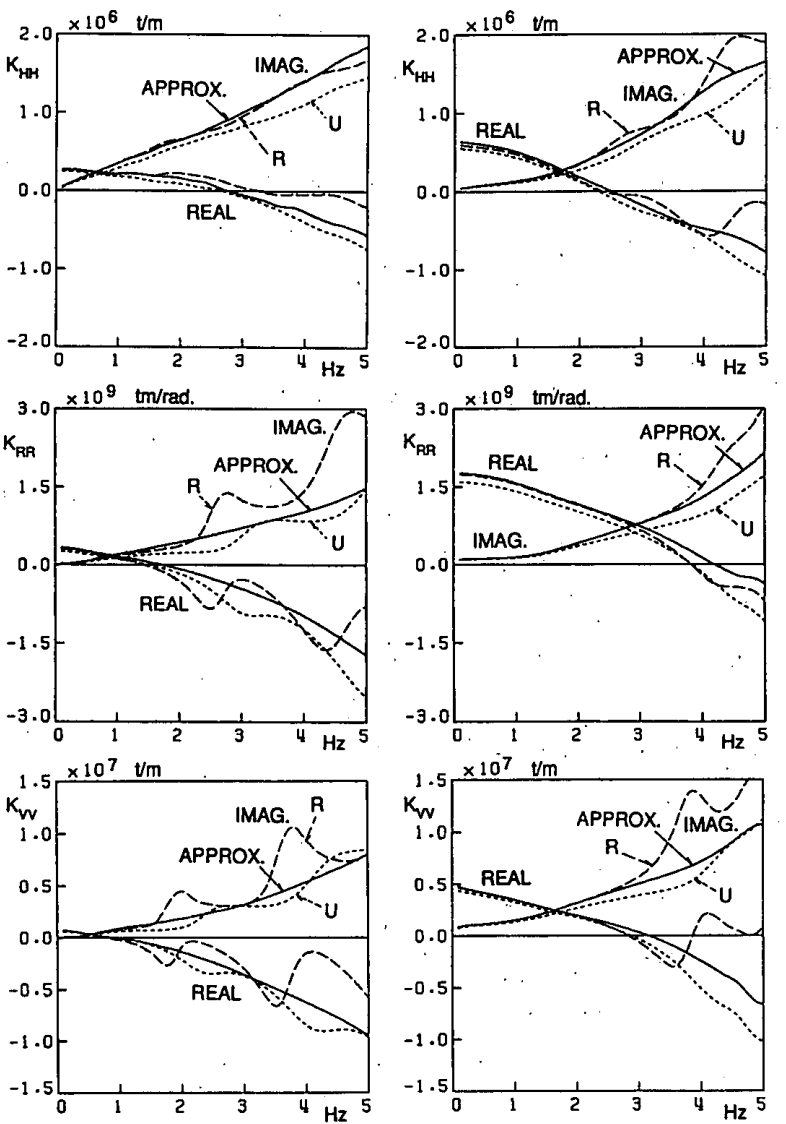

(a) S-1 SOIL

(b) S-2 SOIL

Fig. 14 Dynamic Impedance of $400(20 \times 20)$ Pile Group : $s / D$ $=2.5$

(U : Uniform, R : Rigid Pile Head Force Distribution)
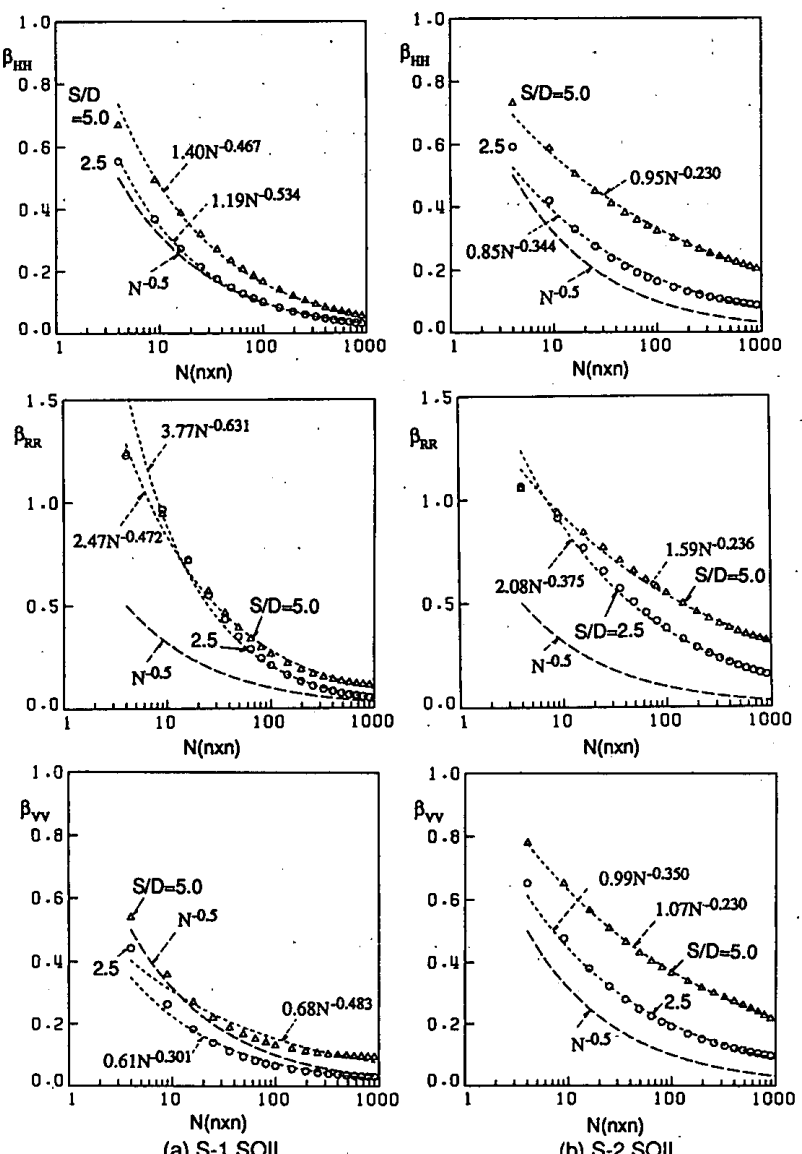

(a) S-1 SOIL

(b) S-2 SOIL

Fig. 15 Efficiency of Pile Group on Static Impedance 
均質地盤（S-1 SOIL）と成層地盤（S-2 SOIL）に関 する群杭係数を示す。これらの図中には通常よく用いら れる群杭係数 $\beta$ と杭本数 $N$ との関係式 $\beta=N^{-0.5}$ および 計算結果を式 $\beta=\alpha N^{-q}$ に回帰した曲線を示す。均質地 盤における杭間距離 $s$ と杭径 $D$ との比すなわち杭間隔 比 $s / D$ が 2.5 の水平の群杭係数 $\beta_{H \mathrm{H}}$ は $\beta=N^{-0.5}$ の曲線 に良く対応しているが, 回転 $\beta_{R R}$ は大きく, 逆に上下 $\beta_{v v}$ は若干小さくなっている。杭間隔比が群杭係数に及 ぼす影響は $\beta_{R R}$ に関してはほとんど認められず， $\beta_{H H}$ と $\beta_{v v}$ に若干見られるのみである。成層地盤における各方 向の群杭係数は， $\beta=N^{-0.5}$ より大きくなり，また均質 地盤に比べ杭間隔比の影響が顥著である。群杭係数を用 いて単杭の静的剛性 $x^{(S)}$ から群杭の静的剛性を評価する 場合には，均質地盤に近い地盤系における水平と上下の 静的㴊性には群杭係数の関係式 $\beta=N^{-0.5}$ をおおむ称適 用できるが，回転および成層地盤においてこの式を用い ると群杭の静的剛性を過小評価することになる。

\section{4. 強制加振実験結果との比較・検討}

前章で記述した群杭の DI の解析は, 単純な層構成の 地盤に関するものである。実在の群杭基礎は層構成がさ らに複雑な地盤に建設され，基礎部は地下室あるいは基 礎フーチングにより埋込みを有する。ここでは，群杭基 礎で実施した強制加振実験結果との比較・検討により略 算法と応力加振法の適用性を調べる。

検討の対象とした群杭基礎は Fig. 16 に示す基礎 A と 基礎 $\mathrm{B}$ である。基礎 $\mathrm{A}$ は平面が約 $51 \mathrm{~m} \times 26 \mathrm{~m}$ で埋込み 深さ $6.5 \mathrm{~m}$ の鉄筋コンクリート基礎である。杭は杭長 $12.5 \mathrm{~m}$ の場所打ちコンクリート杭で, 軸径 $1.5 \mathrm{~m}$ の杭 69 本と軸径 $1.1 \mathrm{~m}$ の杭 15 本の合計 84 本の杭からなる 群杭基礎である。1 階床スラブのコンクリートが打設・

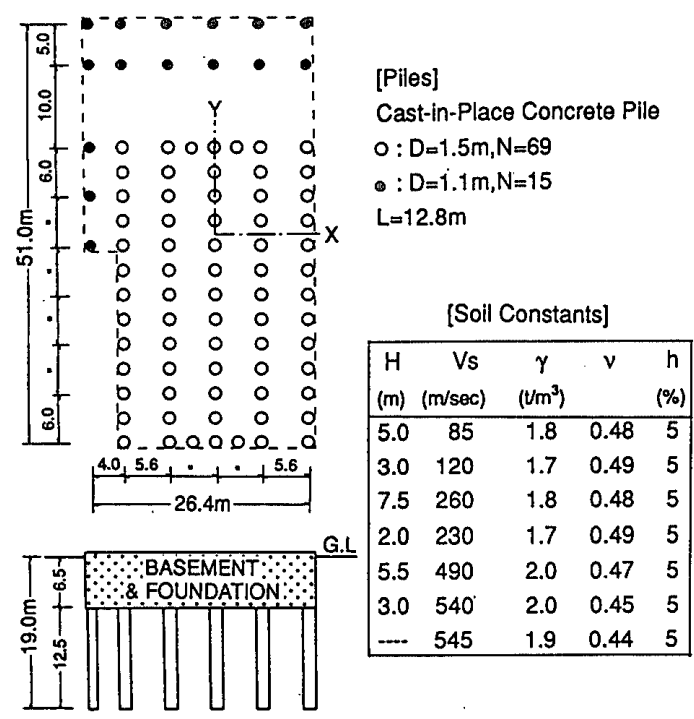

(a) Foundation-A
硬化した後に同床に起振機を設置して水平方向加振実験 を実施した。基礎 $\mathrm{B}$ は平面が約 $54 \mathrm{~m} \times 51 \mathrm{~m}$ で埋込み深 さ $11.9 \mathrm{~m}$ の鉄筋コンクリート基礎である。杭は杭長 $31.1 \mathrm{~m}$, 軸径 $0.8 \mathrm{~m}$ の鋼管杭 492 本の群杭基礎である。 床付けレベルが $\mathrm{GL}-11.9 \mathrm{~m}$ で $4.4 \mathrm{~m}$ 厚の基整フーチ ングのコンクリートが打設・硬化した後に，この基礎 フーチング上に起振機を設置して水平方向加振実験を実 施した。両基礎での実験は加振力レベルは低く，線形の 範囲での強制加振実験である。計測は水平と上下の変位 計を基礎各部に配置して行った。計測された上下変位に は基礎の回転による上下変位の他に基礎の面外弾性変形 による変位が含まれていることが確認されたが，ここで の計測結果の整理は基礎が剛体振動している仮定の基 に，全計測点の変位を用いた最小 2 乗法により基礎底面 中心位置での加振方向変位 $U_{0}$ と直交軸回り回転角 $\phi_{0}$ を 算出した。したがって, 面外弾性変形を無視した剛体基 礎として回転角 $\phi_{0}$ を算出しているために，算出された 回転角には誤差が含まれているものと考えられる。

解析は, 杭頭位置を地表面として略算法と剛版分布の 応力加振法で算定した群杭基礎の DI と文献 14）によ る単位深さ当たりの基礎埋込み部側面水平ば权 $K_{\text {HS }}$ を 考慮して行った。剛体に仮定した基礎の底面での並進力 $F$, モ一メント $M$ と水平変位 $U_{0}$, 回転角 $\phi_{0}$ 上は次の 関係にある。

$$
\begin{aligned}
& F=\left(K_{H H}+E \cdot K_{H(S)}\right) U_{0}+\left\{K_{H R}+\left(E^{2} / 2\right) K_{H(S)} \mid \phi_{0}\right.
\end{aligned}
$$

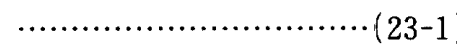

$$
\begin{aligned}
& M=\left\{K_{H R}+\left(E^{2} / 2\right) K_{H(S)\}}\right\} U_{0}+\left\{K_{R R}+\left(E^{3} / 3\right) K_{H(S)}\right\} \phi_{0}
\end{aligned}
$$

ここに, $E$ は基礎の埋込み深さ（基礎 $\mathrm{A}: 6.5 \mathrm{~m}$, 基礎 $\mathrm{B}: 4.4 \mathrm{~m}$ ) である。解析は剛体基礎が（23）式の力〜 変位関係にある動的ばねで支持されたスウェイ・ロッキ

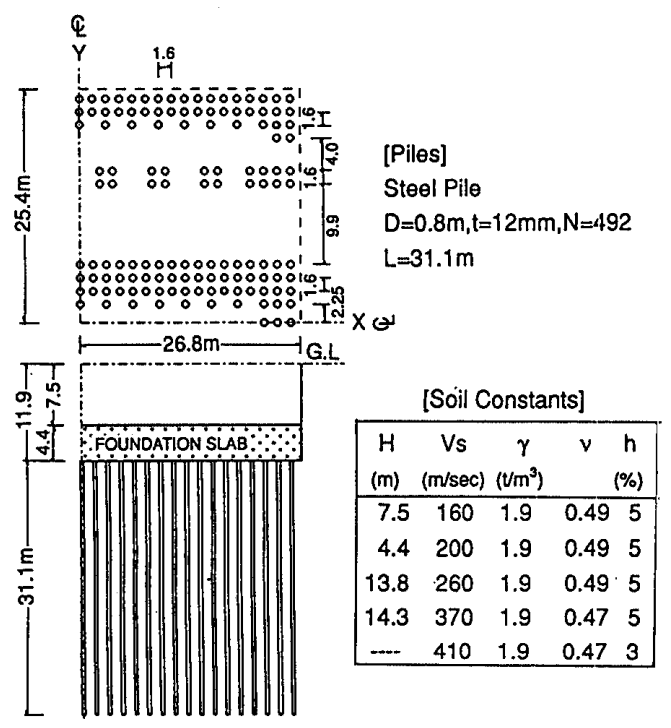

(b) Foundation-B

Fig.16 Pile Group Foundations 

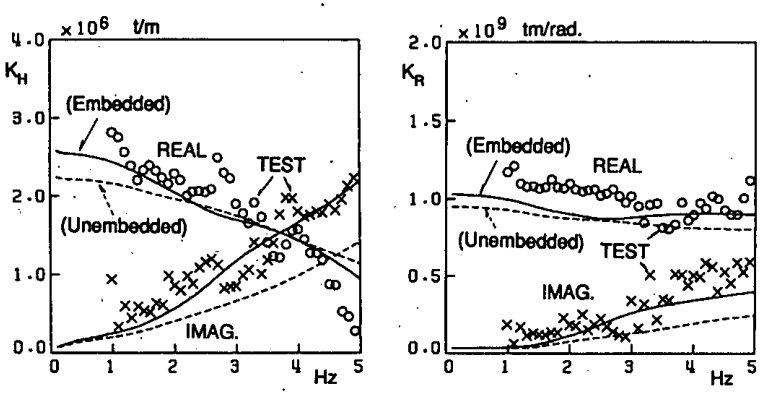

Fig. 17 Dynamic Impedance for Foundation-A in X-Direction Excitaion
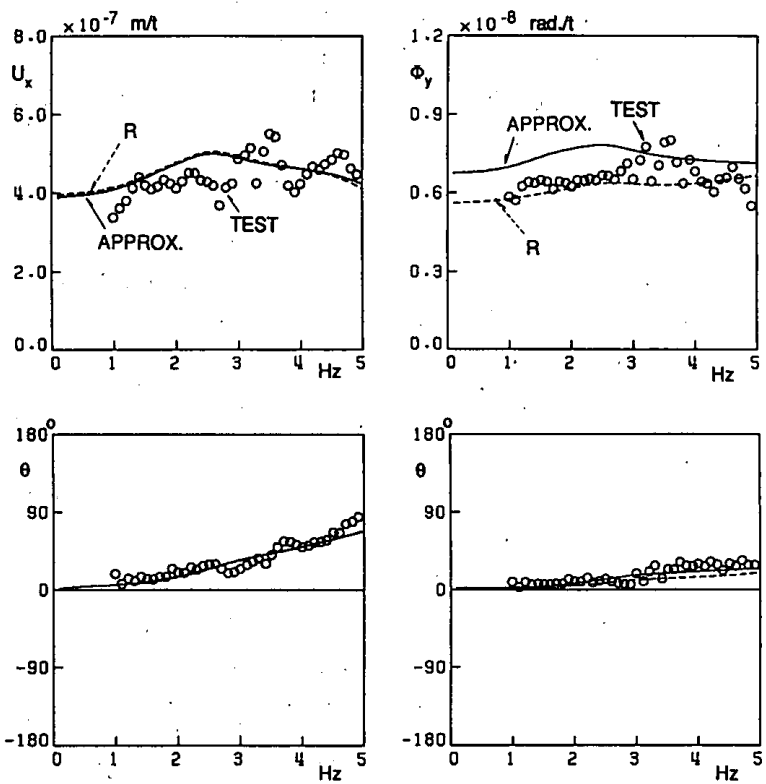

Fig. 19 Resonance and Phase-Lag Curves for Foundation-A in $\mathrm{X}$-Direction Excitaion

ングモデルで実験をシミュレーションすることにより 行うた。実験および解析の $D I$ は，加振力と基礎の慣性 力から基礎底面での並進力 $F$, モーメント $M$ を計算し， 次式により求めた。

$$
\begin{aligned}
& K_{H}=F / U_{0} \\
& K_{R}=M / \phi_{0}
\end{aligned}
$$

ここに， $K_{H}$ と $K_{R}$ は水平と回転の $D I$ であり，基礎の埋 込文の影響と群杭基礎の $D I$ の連成項 $K_{H R}$ をも含む量で ある。なお，応力加振法では連成項 $K_{H R}$ は算定されず，

\section{この項は考慮されていない。}

略算法 (APPROX.) による水平と回転の DI を実験 值 (TEST) と比較して Fig. 17 と Fig. 18 に示す。同 図には，基礎の埋込みを考慮しない，すなわち（23）式 で $K_{H S)}=0$ とした場合 (Unembedded) の $D I$ も示して いる。基礎 $\mathrm{B}$ の回転 $K_{R}$ を除いた略算法の DI の実部, 虚部は共に実験値に比べ若干小さく評価しているが, $D I$ の持つ振動数特性を良く捕らえている。埋込みを考 慮することにより略算法の DI は当然のことなら実験値 との対応が良くなる。この傾向は $D I$ の虚部において著 しい。
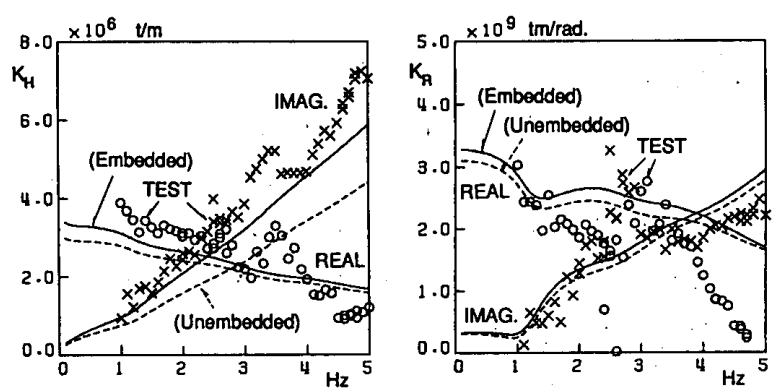

Fig. 18 Dynamic Impedance for Foundation-B in Y-Direction Excitation
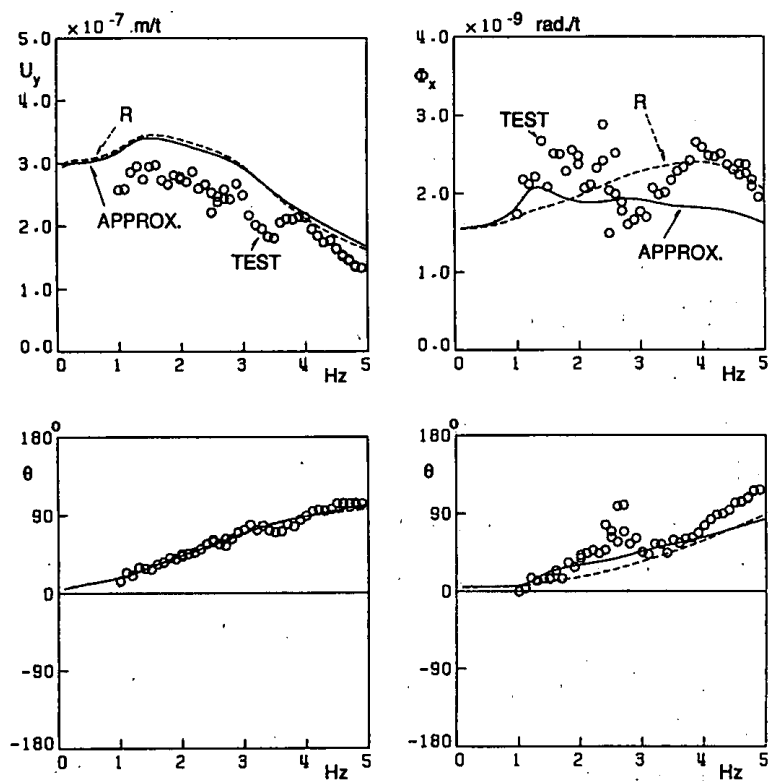

Fig. 20 Resonance and Phase-Lag Curves for Foundation-B in Y-Direction Excitaion

略算法 (APPROX.) と応力加振法 (R) での DI を 用いて計算した共振・位相曲線を実験值と比較して Fig. 19 とFig. 20 に示す。両基礎の実験值の共振曲線 には振幅が盛り上がる振動数が現れているが，これらの 振動数での位相が 90 度付近にないことから基礎-地盤系 の固有振動数に伴う共振ピークとは判断できず, 基礎の 弾性変形などの他の原因により生じたものである。両基 礎での水平変位の共振・位相曲線に関する略算法と応力 加振法との差異は僅少であり，実験值とおおむね対応し ている。回転角の共振・位相曲線に関しては, 基礎 $\mathrm{A} の$

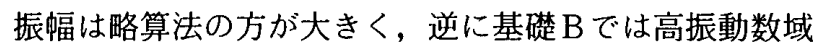
で応力加振法の方が大きくなっている。基礎 Aでは，実 験値の回転角の共振 ・位相曲線の振動数特性を略算法之 応力加振法はおおむね捕らえている。基礎 Bでの回転の $D I$ と回転角の共振・位相曲線は, 他のものに比べ実験 値と解析値との対応が良くない結果となっているが，こ れは基礎 Bの基礎フーチシグ厚が $4.4 \mathrm{~m}$ と薄く, かつ 平面が基礎 $\mathrm{A}$ に比べ大きいことにより，基礎の面外弾性 変形の影響を基礎 $\mathrm{A}$ に比べ強く受けたことによる。 


\section{5. むすび}

本論文は, 杭本数の非常に多い大規模群杭基礎の動的 インピーダンス $(D I)$ の簡便で実用的な解析法としての 略算法と応力加振法を示し, 精度の高い解析法 (精算法) による結果および群杭基礎の強制加振実験結果との比 較・検討により両解析法の適用性を調べたものである。 その結果, 次のことが分かった。

1）略算法での DI は精算法に比べ若干小さくなるが, その差異は杭支持構造物の地震応答解析を行う上で支 障のない程度である。

2）略算法と精算法の演算時間の比は, 例えば 64 本群 杭基礎で約 $1 / 20$ となり, 略算法により演算時間が大 幅に短縮する。

3）均質地盤における群杭基礎の水平と上下の静的剛性 の評価には，通常用いられている群杭係数式 $\beta=$ $N^{-0.5}(N$ : 杭本数) がおおむね適用できるが，回転 および成層地盤についてこの式を用いると静的剛性が 過小に評価される。

4）応力加振法での DI は基礎フーチングの拘束効果が 考慮されていないことにより高振動数領域で波打つ特 性が現れる。低振動数領域での DI は，略算法に比べ 若干小さくなるが実用上問題のない程度である。

5）群杭基礎での強制加振実験結果を略算法および応力 加振法での $D I$ を用いてシミュレーション解析した結 果, 解析結果は実験結果に良く対応しており，両方法 の適用性が確認できた。

\section{謝 辞}

本研究にあたり御指導下さいました京都大学名誉教 授, 鹿島建設株式会社・最高技術顧問, 小堀鐸二博士に, また研究の遂行時に貴重な御意見，御協力を下さった鹿 島建設株式会社の関係各位に感謝の意を表します。

\section{Appendix}

杭頭外力分布について

辺長が $2 a$ の正方形基礎フーチングを有する群杭基礎の中立 軸を $x, y$ 軸とし, I 杭の杭頭坐標値を $\left(x_{i}, y_{l}\right)$ とする。この 杭の基礎の水平 $F_{x}$ ，上下 $F_{z}$ ，モ一メント $M_{y}$ 加振時の杭頭外力 $\left(p_{x}^{\prime \prime}, p_{z}^{n}, p_{z}^{n}\right)$ 分布は次式による。

- 一様分布

$F_{x}$ 加振時: $p_{x}^{\prime \prime}=1$

$F_{z}$ 加振時 $: p_{z}^{n=1}$

$M_{y}$ 加振時 : $p_{z}^{\prime \prime}=x_{t}$

- 剛版分布

$F_{x}$ 加振時 : $p_{x}^{n=1}=1 / f\left(a, x_{i}, y_{i}\right)$

$F_{z}$ 加振時 : $p_{z}^{n}=1 / f\left(a, x_{i}, y_{i}\right)$

$M_{y}$ 加振時: $p_{z}^{\prime \prime}=x_{i} / f\left(a, x_{i}, y_{i}\right)$

ここに,

$f\left(a, x_{i}, y_{i}\right)=\sqrt{L^{2}-\left(x_{i}^{2}+y_{i}^{2}\right)}$

$L=a / \cos \left\{\tan ^{-1}\left(y_{l} / x_{l}\right)\right\}$

\section{参考文献}

1) Tajimi H. : “Dynamic Analysis of a Structure Embedded in an Elastic Stratum", Proceedings of the Fourth World Conference on Earthquake Engineering, pp. 54 69, 1969

2) Kobori T., R. Minai and K. Baba: "Dynamic Behavior of a Laterally Loaded Pile", Proceedings of the Special. ty Session 10, Ninth International Conference on Soil Mechanics and Foundation Engineering, pp. 175 180, 1977

3) Novak M. and F. Aboul-Ella : "Impedance Functions of Piles in Layered Media", Journal of the Engineering Mechanics Division, ASCE, Vol. 104, EM3, pp.643 661,1978

4) Nogami T. : "Dynamic Group Effect of Multiple Piles under Vertical Vibration", Proceedings of Engineering Mechanics Division, Specialty Conference, ASCE, pp. $750 \sim 754,1979$

5) Kaynia A. M. : "Dynamic Stiffness and Seismic Response of Pile Groups", PH.D. Thesis submitted to the Department of Civil Engineering, M.I. T., 1982

6) Davies T.G., R. Sen and P.K. Banerjee: "Dynamic Behavior of Pile Groups in Inhomogeneous Soil", Journal of Geotechnical Engineering Division, ASCE, No. 12 , pp. $1365 \sim 1379,1985$

7）長谷川正幸：“点加振 3 次元薄層法による群杭基礎の動的 解析”, 第 7 回日本地震工学シンポジウム講演集, pp. $979 \sim 984,1986$

8) Urao K., K. Masuda, E. Kitamura et al. : "Forced Vibration Test and its Analytical Study for Embedded Foundation Supported by Pile Group", Proceedings of the Ninth World Conference on Earthquake Engineering, Vol. III, pp. 673 678, 1988

9）土方勝一郎，三浦賢治，宮本裕司ほか 1 名：“群杭基礎の 振動特性に関する研究”, 日本建築学会構造系論文報告集, 第 408 号, pp. 89 98, 1990

10）野添久視, 日下部菜, 福住忠裕：“単杭の鉛直·水平振動 特性の一簡易評価法”, 日本建築学会構造系論大報告集, 第 438 号, pp. 49 64, 1992

11) Dobry R, and G. Gazetas : "Simple Method for Dynamic Stiffness and Damping of Floating Pile Groups", Geotechnique, 36, pp. 557 574, 1988

12) Gazetas G. and N. Makris: "Dynamic Pile-Soil-Pile Interaction. Part 1 : Analysis of Axial Vibration”, Earthquake Engineering and Structural Dynamics, Vol.20, pp. 115 132, 1991

13) Makris N. and G. Gazetas: "Dynamic Pile-Soil-Pile Interaction. Part 2: Lateral and Seismic Response", Earthquake Engineering and Structural Dynamics, Vol. 21, pp. 145 162, 1992

14）田治見宏，泉川正裕：“埋め込み基礎の侧面地盤剛性につ いて”, 日本建築学会大会学術講演梗概集 (北海道), pp. $591 \sim 592$, 昭和 61 年 8 月

15）喜多村英司, 三浦賢治，増田 潔, 宮本裕司ほか 1 名：“大 規模群杭の動的インピーダンス, (その 1) (その 3)”, 1992 年 8 月, pp. $585 \sim 590$, 日本建築学会大会学術講演 梗概集 (北陸)

（1992 年 10 月 9 日原稿受理，1993 年 2 月 2 日採用決定） 